\title{
STRENGTH CHARACTERISTICS OF GROUNDNUT LEAF/STEM ASH (GLSA) CONCRETE
}

\author{
O. W. OSENI' ${ }^{1}$ M. T. AUDU ${ }^{1 *}$
}

\section{Abstract}

The compressive strength properties of concrete are substantial factors in the design and construction of concrete structures. Compressive strength directly affects the degree to which the concrete can be able to carry a load over time. These changes are complemented by deflections, cracks etc., in the structural elements of concrete. This research investigated the effect of groundnut leaf/ stem ash (GLSA) on the compressive strength of concrete at $0 \%, 5$ $\%, 10 \%$ and $15 \%$ replacements of cement. The effect of the water-cement ratio on properties such as the compressive strength, slump, flow and workability properties of groundnut leaf/stem ash (GLSA) mixes with OPC were evaluated to determine whether they are acceptable for use in concrete structural elements. A normal concrete mix with cement at $100 \%$ (i.e., GLSA at 0\%) with concrete grade $C 25$ that can attain an average strength of $25 \mathrm{~N} / \mathrm{mm} 2$ at 28 days was used as a control at design water-cement ratios of 0.65 and grading of (0.5-32) $\mathrm{mm}$ from fine to coarse aggregates was tested for: (1) compressive strength, and the (2) slump and flow Test. The results and observations showed that the concrete mixes from GLSA at 5 - $15 \%$ ratios exhibit: pozzolanic properties and GLSA could be used as a partial replacement for cement at these percentage mix ratios compared with the control concrete; an increase in the water-cement ratio showed a significant decrease in the compressive strength and an increase in workability. Therefore, it is important that all concrete mixes exude an acceptably designed water-cement ratio for compressive strength characteristics for use in structures, water-cement ratio is a significant factor.

\section{INTRODUCTION}

The quest by governments in developing countries, especially those in the west of the Sahara in Africa, for the use of alternative, unconventional local construction material that is sustainably developed has witnessed a tremendous increase over the years. Organic waste material is available in massive quantities in rural

\section{Address}

1 Department of Civil Engineering, University of Abuja, Nigeria, tosagigal2000@yahoo.com2

* Corresponding author: tosagigal2000@yahoo.com

\section{Key words}

- Ash,

- Concrete,

- Compressive Strength,

- Flow,

- Slump

- Ground nut leave. 
1983; Gram and Nimityoungskul, 1987). Concrete is a composite inert material comprised of a binder (e.g, cement), a mineral filler (aggregates) and water (Neville, 1989). Aggregates are of two types, fine and coarse. They are usually graded from sand to stone. There are two types of concrete: lightweight concrete and normal-weight concrete. The light weight concrete weighs between 1600 to 2000 $\mathrm{kg} / \mathrm{m}^{3}$, while normal-weight concrete has an average density of 2400 $\mathrm{kg} / \mathrm{m}^{3}$ (Orchard, 1976). Normal-weight concrete is often used for reinforced concrete works in suspended structural members, but can also be used as mass concrete for ground floors.

The batching of concrete can either be by weight or by volume. The batching of a design mix for high-quality jobs is usually by weight. The amount of water to be added to a batch of concrete mix is governed by the workability, strength the exposure condition of the concrete. If too much water is added, there is tendency for segregation of the aggregates during placement and the concrete does not meet the target strength after it has hardened. On the other hand, too little water in the mix will not make the chemical action of the setting of the cement incomplete. The amount of water to be added to a given batch of concrete mix is guided by a specified water-cement ratio.

Concrete can also be made impermeable to water by admixing polymers, silicons or stearates. Another method is to admix a small ball of wax in the fresh concrete. The mixture is allowed to harden. Thereafter, it is subjected to heat so that the melting wax flows into the pores of the concrete, thus sealing the system. Impregnating the concrete with sulphur, tar, asphalt or oil also constitutes a possible means of preventing the movement of moisture in the pore system of the concrete (Gram and Nimityoungskul, 1987; Guimaraes, 1990; Sivaraja et al., 2010). The alkalinity of the concrete's pore water can be reduced by replacing some of the ordinary Portland cement (OPC) with various pozzolanas (Yunusa and Danladi, 2013). This is achieved when the calcium hydroxide, which is formed in connection with the cement's hydration, reacts in part with the silica present in the pozzolanas. When the free calcium hydroxide has been completely consumed, the carbonation of the matrix is also facilitated, thus entailing a marked reduction in $\mathrm{pH}$ value for the pore water (Cook, 1986; Suvanispan, 1988). Cements of different bands types have been found suitable as the binding material for concrete. However, cement production involved using mined soil minerals been put into processes that are not easily done by simple mechanisms. These cement materials are localized, and the necessity to import the machinery to produce cement often results in high-priced cement, which ultimately results in making the production of concrete costly. The challenge is therefore or researchers to find alternative materials that could be used to substitute for complement the cement in the production of concrete.

The deployment of viable waste materials in the production of concrete provides a satisfactory solution to some of the environmental concerns and problems associated with waste management in every country of the world. Nigeria is not an exception. Therefore, the need to study the behaviour and/or properties of sustainable waste material such as groundnut leaf/stem ash (GLSA) concrete for building construction cannot be overemphasized. The performance of the entire building structure is a function of the quality of each material that constitutes the building. As a consequence of the importation of most materials, the high cost of both local and imported building materials has made the ownership of a house beyond the reach of most Nigerians (Madedor, 1992). This has resulted in a shortage of accommodation in every urban settlement of the country with the attendant high cost of rent. Consequently, the use of locally produced building materials, including agricultural and industrial waste and products to construct houses, has to be investigated and encouraged. Assessing the use of substitutes and the economic exploitation of naturally occurring local materials and agricultural or industrial waste and products remain important areas of research in the drive towards the overall development of any nation. The current challenge facing the governments of most developing nations like Nigeria is how to provide good accommodations for the growing population at a relatively low cost.

For this research the slump, flow, and compressive strength of the basic concrete mix of grade $\mathrm{C} 25$ at a designed water-cement ratio of 0.60 and 0.65 were examined for:

$0 \%$ GLSA, $100 \%$ Cement (0.5-32) mm fine-coarse aggregate mix concrete (Control),

5\% GLSA, 95\% Cement (0.5-32) mm fine-coarse aggregate mix concrete,

$10 \%$ GLSA, $90 \%$ Cement (0.5-32) $\mathrm{mm}$ fine/coarse aggregate mix concrete,

$15 \%$ GLSA, $85 \%$ Cement (0.5-32) $\mathrm{mm}$ fine-coarse aggregate mix concrete.

\section{METHODOLOGY OF RESEARCH}

The materials, experiments and laboratory works carried out to accomplish the objective of this research are as follows:

\subsection{Materials}

The materials used in the production of the concrete cubes used are sand, gravel, cement, groundnut leaf/stem ash and water.

\subsubsection{Sand}

The sand was obtained at in the environs of Gwagwalada-AbujaFCT and transported to Julius Berger PLC (JBN PLC), Quality Assurance \& ControL (QA\&C) Laboratory, Mpape-Abuja, FCT, for a preliminary analysis for its suitability for use in concrete production.

\subsubsection{Gravel}

The coarse aggregate was obtained from Gwagwalada-AbujaFCT and transported to JBN PLC, QA\&C Laboratory, Mpape-Abuja, FCT. The aggregate was washed and allowed to dry naturally to free it from dirt and impurities according to BS 812, 1975.

\subsubsection{Cement}

The cement used was Dangote cement, which was obtained at Gwagwalada-Abuja-FCT. The cement obtained was ordinary Portland cement and, as such, was found to be applicable in most construction works. It was stored in a place with no direct contact with floor and walls. An analysis of the grain size of the cement was carried out to determine its suitability for the work.

\subsubsection{Groundnut leaf/stem ash}

Groundnut Leaf/Stem is a waste product from millet farms in the rural areas of FCT, Niger State and Kaduna State. The Groundnut Leaf/Stem obtained was sorted into sacks to avoid mixing it with materials that were already decayed or rotting from moisture or rain and was transported to the JBN PLC, QA\&C Laboratory, MpapeAbuja FCT. The burning of the Groundnut Leaf/Stem was done at a laboratory using an oven. 


\subsubsection{Water}

The source of the water used for this work was borehole water situated in the JBN PLC, QA\&C Laboratory, Mpape-Abuja, FCT. The water was potable, which therefore satisfied the required specification for making concrete as described in BS 3148 and was therefore suitable for the production of concrete.

\subsection{Experimental procedures}

The study commenced with the collection of groundnut leaf/stem from farms around Abuja-Niger-Kaduna-Zaria. The groundnut leaf/ stem was burnt and its ashes collected. The ashes were allowed to pass through a 0.63 millimetre to sieve to achieve the same degree of fineness cement. This was followed by a preliminary investigation of the constituent material of ordinary Portland cement (OPC) and the groundnut leaf/stem ash (GLSA).

\subsection{Laboratory tests}

In accordance with the various codes, the following preliminary tests were conducted on the materials at room temperature and under laboratory conditions to determine their suitability for making concrete: the specific gravity test (CP100); aggregate impact value test (BS 812); silt content test (BS 11975); moisture content test; and sieve snalysis test;

\subsubsection{Batching}

The materials were batched by weight; the measurement was performed as usual using a head pan and a balance.

\subsection{Mix design}

The concrete mix was designed in accordance with the British design mix BS 8110. The method gives proportions in terms of the quantities of the materials per unit volume of concrete. The mixing was done using a rotary concrete mixer. The fine and coarse aggregates, cement, and millet husk ash were all mixed together in the concrete mixer thoroughly to achieve final degree of uniformity. The required quantity of water with a water-cement ratio of 0.75 was then added.

\subsection{Slump /flow test}

A slump test was carried out to determine the workability of the concrete. The slump cone was placed on a flat non-porous surface and held down by foot. The mould was then filled in three layers. Each layer was compacted. After the third layer had been tamped, the slump cone was immediately removed by raising it vertically. The height of the slump cone was determined by taking measurement from the top of the slump cone to the top of the concrete. The slump was measured as the difference between the height of the cone and the height of the slump concrete, see Figure 1. The flow test was carried out on fresh composite concrete using the various percentages of ground nut leave ash. The flow table was wetted. The flow test cone was placed on the flow table and then filled with the composite concrete in two layers; each layer was tamped 10 times. The cone was lifted up after 30 seconds. The concrete was allowed to flow. The table was then lifted up $40 \mathrm{~mm}$ and dropped 15 times. The diameter of spread of the fresh concrete composite on the flow table was measured as shown in Figure 2.

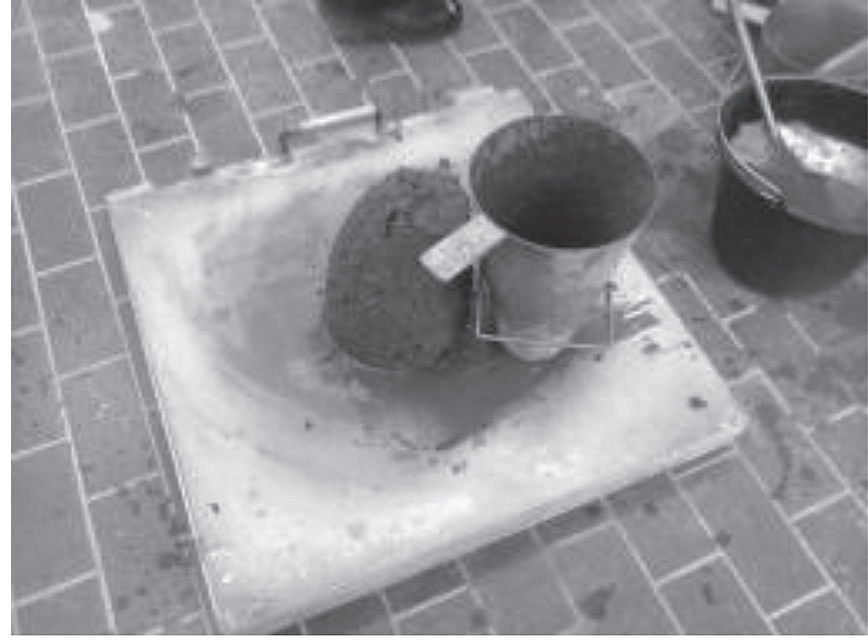

Fig. 1 Slump Test

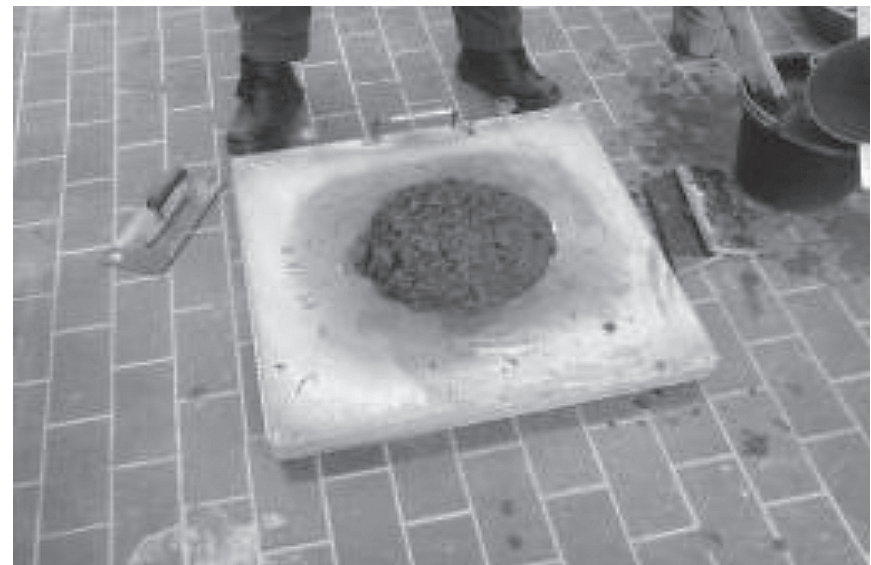

Fig. 2 Flow Test

\subsection{Compressive strength test}

Cube moulds of the size $150 \mathrm{~mm} \times 150 \mathrm{~mm} \times 150 \mathrm{~mm}$ were used for the casting for the compressive strength test. The concrete was placed in three layers, and each layer was tamped. The surface of the concrete was smoothened with a steel float and then covered with a sack and left for $24 \mathrm{hrs}$ in the laboratory.

The concrete cubes were then unmoulded and immediately placed in moist curing tanks for 7, 21, 28 and 56 days. After each of the stated days, the cubes (Figure 3 ) were removed from the tank and allowed to dry in the open air for 2 hours before being subjected to a compressive strength test.

The compressive strength of the cube samples was determined in accordance with the standard procedure given in BS 2080 (BSI, 1970) as shown in Figure 4. The weights of the sample were always taken before the compressive strength test was conducted. Three cubes samples were crushed on the $3^{\text {rd }}, 7^{\text {th }}, 14^{\text {th }}, 21^{\text {st }}$ and $28^{\text {th }}$ days respectively. The maximum load carried by the specimen before failure occurred was recorded. The compressive strength was calculated using the following formula

Compressive strength $=\mathrm{F} / \mathrm{A}$

where $\mathrm{F}=$ Failure load $(\mathrm{N})$ and $\mathrm{A}=$ Cross-sectional area $\left(\mathrm{mm}^{2}\right)$. 


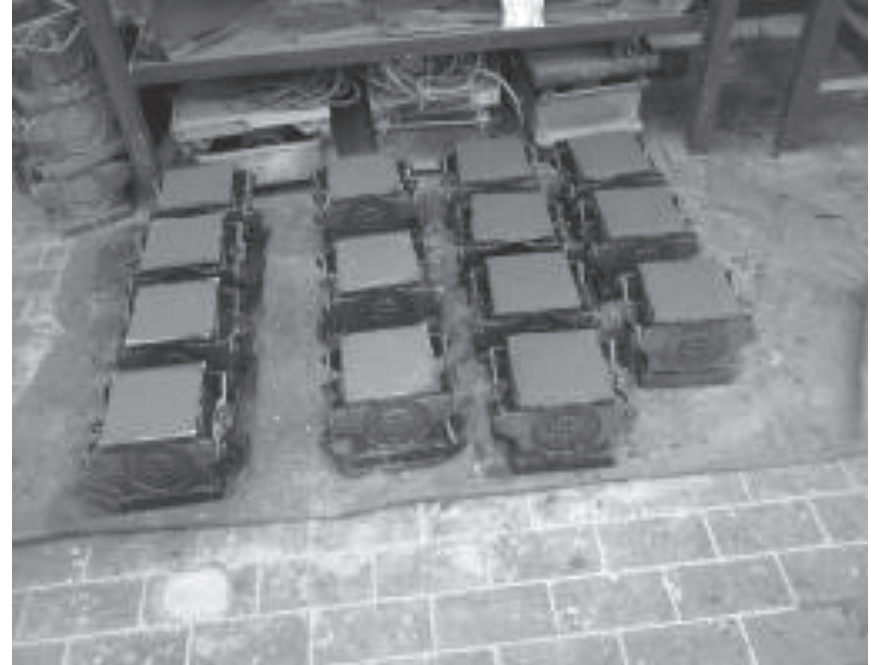

Fig. $3150 \times 150 \times 150 \mathrm{~mm}$ cube samples

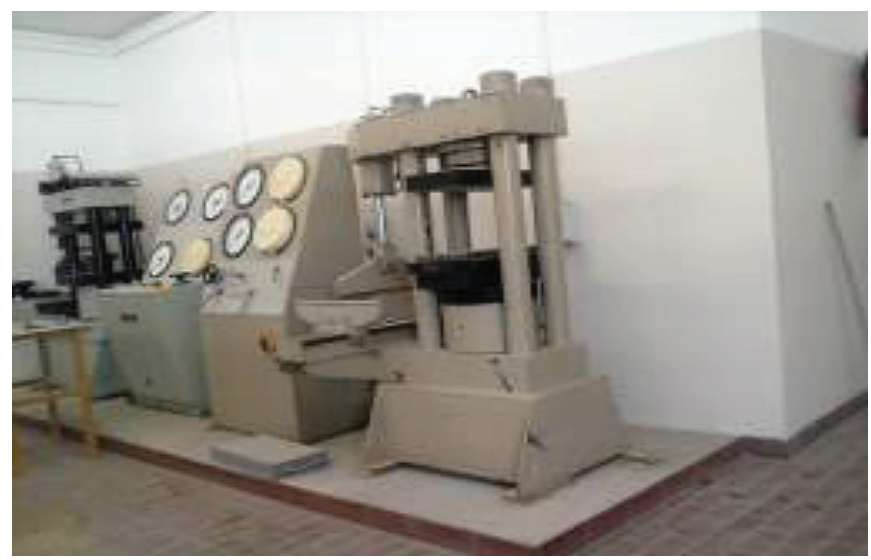

Fig. 4 Compressive Strength Test

\section{RESULTS AND DISCUSSION}

\subsection{Fresh concrete properties}

The slump and flow tests were used to evaluate the workability and consistency of the fresh concrete.

The experiment showed that as the percentage of GLSA was increased in the mix, these was a greater decrease in the slump and flow. Hence, there was an increase in workability as shown in Table 1 and Figure 5. It was also observed that there was a change in the colour of the concrete from ash to dark ash with the increases in the percentage of ground nut leaf ash.

Tab. 1 Slump and flow at a water-cement ratio of 0.60 for concrete grade $C 25$

\begin{tabular}{|c|c|c|}
\hline $\begin{array}{c}\text { \% Replacement at water-cement ratio } \\
\text { of 0.75 and concrete grade C25 }\end{array}$ & $\begin{array}{c}\text { Slump test } \\
\text { (mm) }\end{array}$ & $\begin{array}{c}\text { Flow test } \\
\text { (mm) }\end{array}$ \\
\hline $100 \% \mathrm{OPC}, 0 \%$ GLSA & 75 & 430 \\
\hline $95 \% \mathrm{OPC}, 5 \%$ GLSA & 65 & 430 \\
\hline $90 \% \mathrm{OPC}, 10 \%$ GLSA & 43 & 390 \\
\hline 85\%OPC, 15\% GLSA & 43 & 400 \\
\hline
\end{tabular}

\section{Graph1: Slump/Flow Vs \% replacement at $0.60 \mathrm{w} / \mathrm{c}$ ratio}

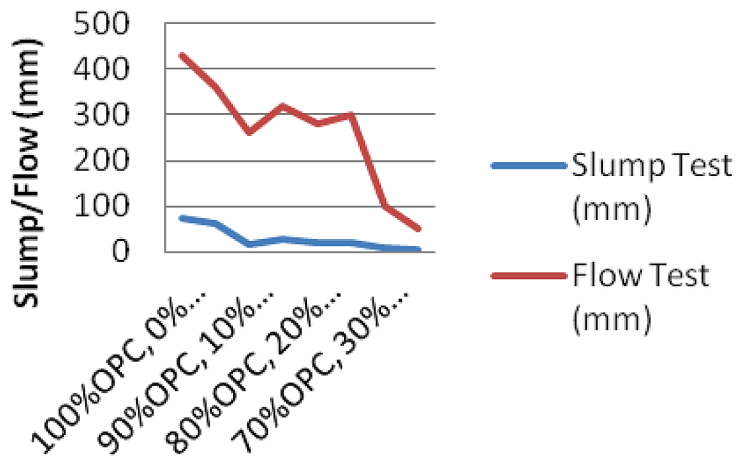

Fig. 5 Slump and flow test

Tab. 2 Slumps and flow test of GLAC at a water-cement ratio of 0.65 for concrete grade $C 25$

\begin{tabular}{|c|c|c|}
\hline $\begin{array}{c}\text { \% Replacement at water cement ratio } \\
\text { of 0.65 and concrete grade C25 }\end{array}$ & $\begin{array}{c}\text { Slump Test } \\
(\mathbf{m m})\end{array}$ & $\begin{array}{c}\text { Flow Test } \\
(\mathbf{m m})\end{array}$ \\
\hline $100 \% \mathrm{OPC}, 0 \%$ GLSA & 145 & 430 \\
\hline $95 \% \mathrm{OPC}, 5 \%$ GLSA & 195 & 510 \\
\hline $90 \% \mathrm{OPC}, 10 \%$ GLSA & 62 & 350 \\
\hline $80 \% \mathrm{OPC}, 20 \%$ GLSA & 110 & 420 \\
\hline $75 \% \mathrm{OPC}, 25 \%$ GLSA & 90 & 400 \\
\hline
\end{tabular}

\subsection{Fresh concrete properties:}

The slump and flow tests were used to evaluate the workability and consistency of the fresh concrete.

The experiment showed that as the percentage of GLSA was increased in the mix, there was a greater decrease in the slump and flow. Hence, there was an increase in workability as shown in Tables 1 and 2, while Figures 5 and 6 clearly showed the trend in the slump and flow with the changes in the percentage composition of GLSA and then water-cement ratio. It was also observed that there was a change in the colour of concrete from ash to dark ash with the increased percentages of ground nut leaf ash.

Tab 3 Compressive strength at a water-cement ratio of 0.60 for concrete grade $\mathrm{C} 25$

\begin{tabular}{|c|c|c|c|c|}
\hline \multirow{2}{*}{$\begin{array}{c}\text { \% Replacement at water- } \\
\text { cement ratio of 0.60 and } \\
\text { concrete grade C25 }\end{array}$} & \multicolumn{4}{|c|}{ Compressive Strength (N/mm2) } \\
\cline { 3 - 6 } & days & 21 days & $\mathbf{2 8}$ days & $>\mathbf{5 6}$ days \\
\hline $100 \%$ OPC, 0\% GLSA & 29.8 & 34.4 & 34.2 & 38.2 \\
\hline $95 \%$ OPC, 5\% GLSA & 28.9 & 35.8 & 35.1 & 36.4 \\
\hline $90 \%$ OPC, 10\% GLSA & 20.9 & 23.8 & 23.8 & 27.6 \\
\hline $85 \%$ OPC, 15\% GLSA & 16 & 20.2 & 20.4 & 22.2 \\
\hline $80 \%$ OPC, 20\% GLSA & 14.4 & 17.3 & 18.2 & 17.8 \\
\hline $75 \%$ OPC, 25\% GLSA & 15.6 & 18.9 & 19.6 & 20.8 \\
\hline $70 \%$ OPC, 30\% GLSA & Collapsed and failed during curing \\
\hline in the curing tank
\end{tabular}




\section{Graph 3: Compressive Strength vs days of crushing}

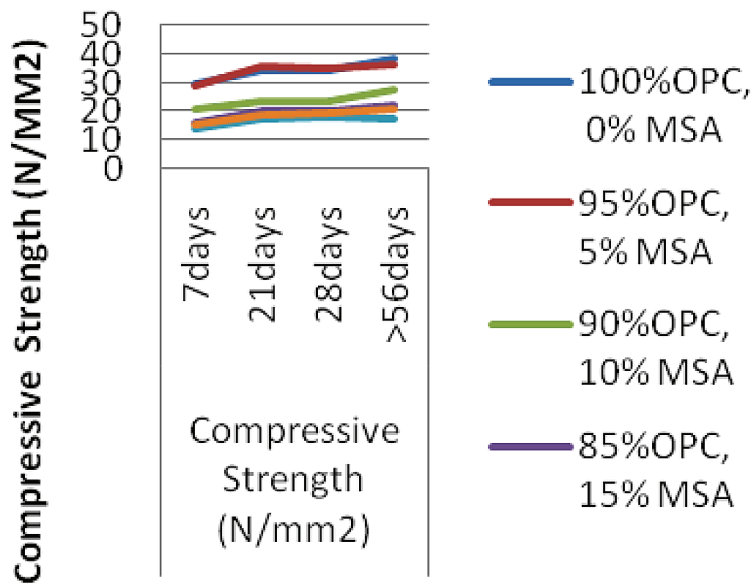

Fig. 6 Compressive strength of groundnut leaf cement concrete composite at 0.60 water-cement ratio

Tab. 4 Compressive strength at water cement ratio of 0.65 for concrete grade $C 25$

\begin{tabular}{|c|c|c|c|c|}
\hline \multirow{2}{*}{$\begin{array}{l}\text { \% Replacement at water- } \\
\text { cement ratio of } 0.65 \text { and } \\
\text { concrete grade } \mathrm{C} 25\end{array}$} & \multicolumn{4}{|c|}{ Compressive Strength (N/mm²) } \\
\hline & 7 days & 21 days & 28 Days & $>56$ days \\
\hline $100 \% \mathrm{OPC}, 0 \%$ GLSA & 23.3 & 28.9 & 28 & 30.7 \\
\hline $95 \% \mathrm{OPC}, 5 \%$ GLSA & 20.4 & 23.8 & 23.3 & 24.9 \\
\hline $90 \% \mathrm{OPC}, 10 \% \mathrm{GLSA}$ & 13.6 & 15.1 & 11.1 & 17.8 \\
\hline $80 \%$ OPC, $20 \%$ GLSA & 12.2 & 13.6 & 14.2 & 14.2 \\
\hline $75 \% \mathrm{OPC}, 25 \%$ GLSA & 12.7 & 14.0 & 14.7 & 14.7 \\
\hline
\end{tabular}

Graph4: Compressive Strength Vs Days of Crushing for w-c ratio of 0.65

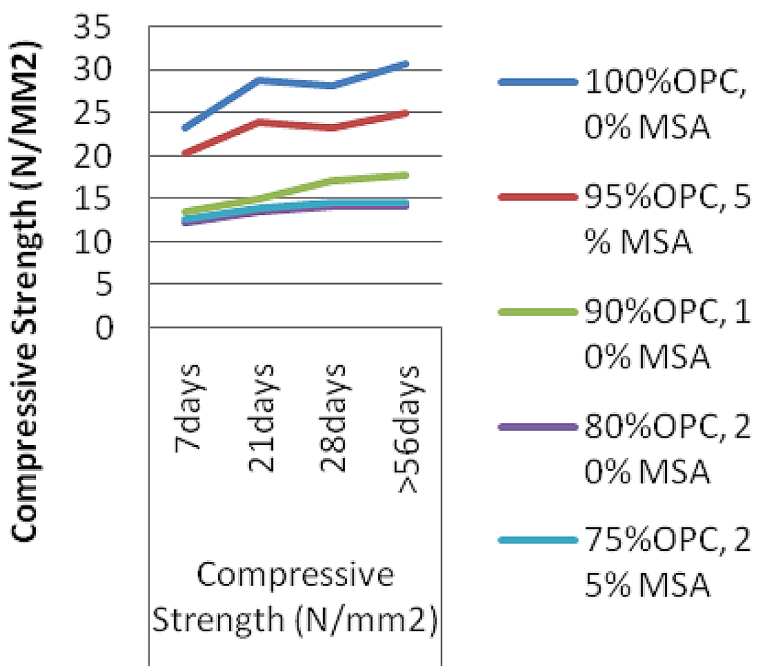

Fig. 7 Compressive strength of groundnut leaf cement concrete composite at 0.65 water-cement ratio

\subsection{Hardened Concrete Properties}

\subsubsection{Compressive Strength of GLSA Concrete}

The compressive strength of the concrete decreased as the percentage replacement of GLSA increased from 5-25\% compared with the $0 \%$ GLSA. The compressive strength dropped by $20-30 \%$ with an increase in the water-cement ratio from 0.60 to 0.65 (see Figures 7 and 8).

The dried density and weight are presented in Tables 5 and 6. It can be observed from the graphic illustrations of the weight and dry density of the GLSA concrete shown in Figures 8 to 11 that both the dry density and weight decrease with any increase in the percentage of GLSA. These properties also decrease with an increase in the watercement ratio and an increase in the elapsed time before crushing.

Tab. 5 Weight and density at a water-cement ratio of 0.60 for concrete grade $C 25$

\begin{tabular}{|c|c|c|c|}
\hline $\begin{array}{c}\% \text { Replacement at water- } \\
\text { cement ratio of } 0.60 \text { and } \\
\text { concrete grade } \mathbf{C} 25\end{array}$ & $\begin{array}{c}\text { Crushing } \\
\text { Days }\end{array}$ & $\begin{array}{c}\text { Weight } \\
\text { (kg) }\end{array}$ & $\begin{array}{l}\text { Density } \\
\left(\mathrm{kg} / \mathrm{m}^{3}\right)\end{array}$ \\
\hline \multirow{5}{*}{$0 \%$} & 7 & 7.961 & 2359 \\
\hline & 21 & 7.959 & 2358 \\
\hline & 28 & 8.090 & 2397 \\
\hline & $>56$ & 8.014 & 2375 \\
\hline & Average & 8.006 & 2372 \\
\hline \multirow{5}{*}{$5 \%$} & 7 & 7.980 & 2364 \\
\hline & 21 & 8.026 & 2378 \\
\hline & 28 & 8.015 & 2375 \\
\hline & $>56$ & 7.968 & 2361 \\
\hline & Average & 7.997 & 2370 \\
\hline \multirow{5}{*}{$10 \%$} & 7 & 7.866 & 2331 \\
\hline & 21 & 7.889 & 2337 \\
\hline & 28 & 7.926 & 2348 \\
\hline & $>56$ & 7.880 & 2335 \\
\hline & Average & 7.890 & 2338 \\
\hline \multirow{5}{*}{$15 \%$} & 7 & 7.971 & 2362 \\
\hline & 21 & 7.983 & 2365 \\
\hline & 28 & 7.995 & 2369 \\
\hline & $>56$ & 7.991 & 2344 \\
\hline & Average & 7.985 & 2360 \\
\hline \multirow{5}{*}{$20 \%$} & 7 & 7.833 & 2321 \\
\hline & 21 & 7.871 & 2332 \\
\hline & 28 & 7.890 & 2338 \\
\hline & $>56$ & 7.873 & 2333 \\
\hline & Average & 7.867 & 2331 \\
\hline \multirow{5}{*}{$25 \%$} & 7 & 7.953 & 2356 \\
\hline & 21 & 7.953 & 2356 \\
\hline & 28 & 7.926 & 2348 \\
\hline & $>56$ & 7.883 & 2336 \\
\hline & Average & 7.929 & 2349 \\
\hline
\end{tabular}




\section{Graph5: Weight Vs Crushing Days at \% Replacements of 0.60 water cement ratio}

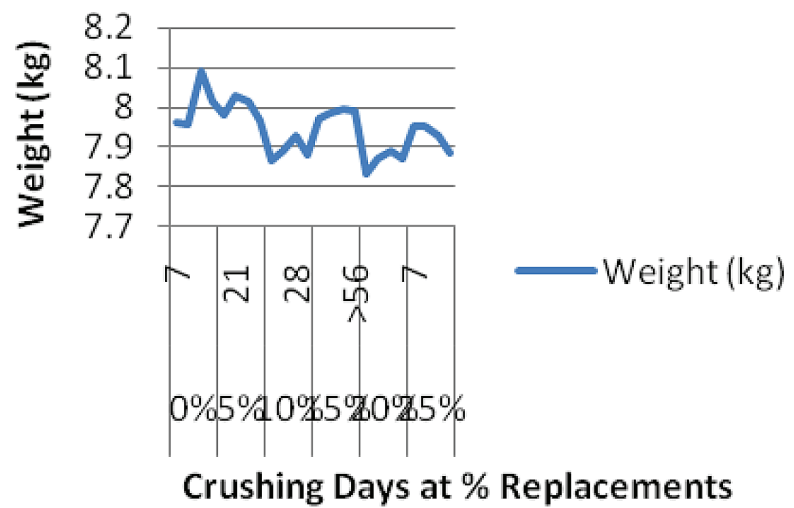

Fig. 8 The weight of the groundnut leaf cement concrete composite at 0.60 water-cement ratio

Tab. 6: Density and weight of concrete composites at a watercement ratio of 0.65 for concrete grade $C 25$

\begin{tabular}{|c|c|c|c|}
\hline $\begin{array}{c}\text { \% Replacement at water- } \\
\text { cement ratio of } 0.65 \text { and } \\
\text { concrete grade } \mathrm{C} 25\end{array}$ & $\begin{array}{c}\text { Number of } \\
\text { days before } \\
\text { crushing }\end{array}$ & $\begin{array}{c}\text { Weight } \\
\text { (kg) }\end{array}$ & $\begin{array}{l}\text { Density } \\
\left(\mathrm{kg} / \mathrm{m}^{3}\right)\end{array}$ \\
\hline \multirow{5}{*}{$0 \%$} & 7 & 7.889 & 2337 \\
\hline & 21 & 7.869 & 2331 \\
\hline & 28 & 7.916 & 2345 \\
\hline & $>56$ & 7.874 & 2333 \\
\hline & Average & 7.887 & 2337 \\
\hline \multirow{5}{*}{$5 \%$} & 7 & 7.942 & 2353 \\
\hline & 21 & 7.974 & 2363 \\
\hline & 28 & 7.916 & 2345 \\
\hline & $>56$ & 7.882 & 2335 \\
\hline & Average & 7.929 & 2349 \\
\hline \multirow{5}{*}{$10 \%$} & 7 & 7.836 & 2320 \\
\hline & 21 & 7.827 & 2319 \\
\hline & 28 & 7.882 & 2335 \\
\hline & $>56$ & 7.866 & 2331 \\
\hline & Average & 7.853 & 2326 \\
\hline \multirow{5}{*}{$20 \%$} & 7 & 7.955 & 2357 \\
\hline & 21 & 7.926 & 2348 \\
\hline & 28 & 7.923 & 2348 \\
\hline & $>56$ & 7.959 & 2358 \\
\hline & Average & 7.941 & 2353 \\
\hline \multirow{5}{*}{$25 \%$} & 7 & 7.790 & 2308 \\
\hline & 21 & 7.765 & 2301 \\
\hline & 28 & 7.806 & 2313 \\
\hline & $>56$ & 7.717 & 2287 \\
\hline & Average & 7.770 & 2302 \\
\hline
\end{tabular}

Graph6: Density Vs Crushing Days at \% Replacement for 0.60 water cement ratio

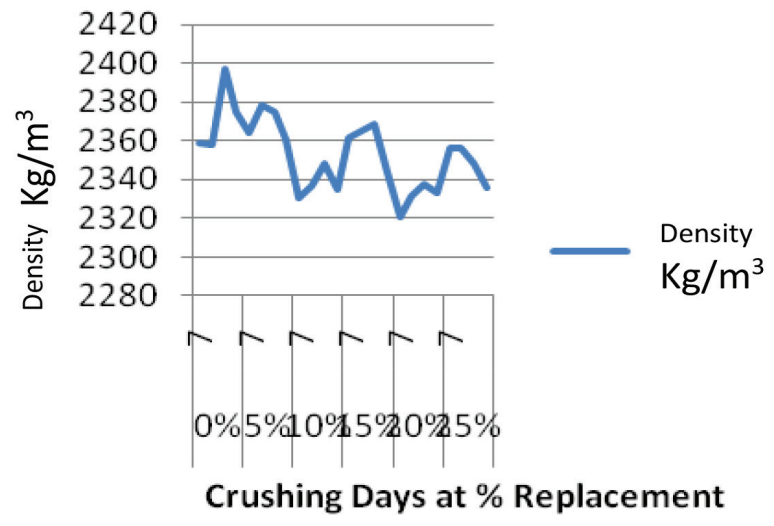

Fig. 9 The density of ground nut leaf cement concrete composite at 0.60 water/cement ratio

Graph7: Weight Vs crushing Days at \% Replacement for 0.65 Water cement Ratio

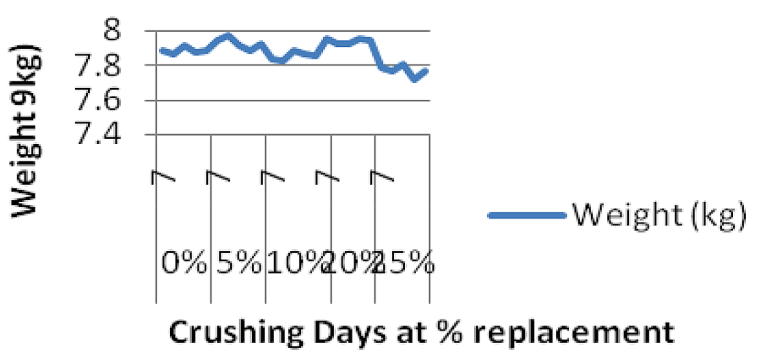

1

Fig. 10 The weight of groundnut leaf cement concrete composite at 0.65 water-cement ratio

Graph8: Density Vs Crushing Days at \% replacement for $\mathbf{0 . 6 5}$ Water Cement Ratio

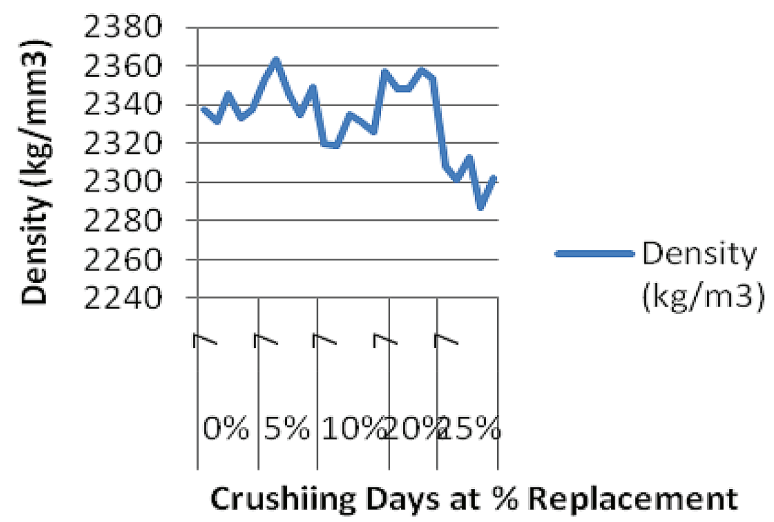

Fig. 11 The density of groundnut leaf cement concrete composite at 0.65 water-cement ratio 


\section{CONCLUSION}

The results from this research show that:

(1) GLSA concrete can be used to replace of Portland cement in concrete

(2) The compressive strength of GLSA concrete shows that the mechanical property for the concrete even at 28 days is 20 $\mathrm{N} / \mathrm{mm} 2$ for $25 \%$ GLSA concrete and is influenced by the increase in the water-cement ratio. It reduced the compressive strength significantly.

(3) The density of GLSA concrete is quite comparable with normal concrete at $0 \%$ GLSA, even with the increase in the water-cement ratio.

(4) The workability of the concrete decreases as the percentage of GLSA increases, but it is still workable with a $25 \%$ GLSA replacement.

Further studies should be focused on:

(i) The chemical characterisation of the Millet Stem Ash

(ii) Morphology and microstructure of concrete made from GLSA concrete.

(iii) Influence of the Initial and final set time of GLSA concrete.

(iv) The shrinkage and creep test to determine the long-term suitability of GLSA concrete for structural elements in structures is still in progress.

\section{RECOMMENDATIONS}

All of the GLSA concrete samples evaluated for C25 and the water-cement ratio revealed that:

(1) GLSA concrete could be used for concrete at a $15 \%$ replacement with a water-cement ratio of 0.60 and $5 \%$ at water cement ratio of 0.65 .

(2) GLSA concrete is of the same weight and density of a normal concrete at $0 \%$ but decreases as the percentage of GLSA increases.

(3) The workability of GLSA concrete decreases as the percentage of GLSA increases; it becomes unworkable at a water-cement ratio of 0.60 but is more workable at a 0.65 water-cement ratio. 


\section{REFERENCES}

American Society for Testing Materials, ASTM (1981): C618, Specification for Fly Ash and Raw or Calcined Natural Pozzolana for Use as Mineral/Admixture in Portland Cement.

American Society for Testing Materials, ASTM C-157 "Standard Test Method or Length Change of Hardened Hydraulic-Cement Mortar and Concrete"

American Society for Testing Materials, ASTM C-512 "Standard Test Method for Creep in Compression".

ASTM C 33: Standard Specification for Concrete Aggregates. - Annual Book of ASTM Standards, 1994.

ASTM C 109: Standard Test Method for Compressive Strength of Hydraulic Cement Mortars, 1993.

ASTM C 512: Standard Test Method for Creep of Concrete in Compression, 1992.

Bamidele, I. - Dahunsi, O. (2002): 'Properties of Periwinkle-Granite Concrete'. Journal of Civil Engineering, JKUAT. Vol. 8, 2002. pp. 27-36.

British Standard Institution (1973): BS12, Ordinary and Rapidly Hardening Portland Cement.

British Standard Institution (1995): BS812, Testing Aggregates.

British Standard Institution (1997): BS5328, Method of Specifying Concrete Mixes.

Duna, S. - Mofoke, A. L. E. (2004): "Evaluation of Some Engineering Properties of Laterite Blocks Made with Extracts of Locust Beans". Nigerian Journal of Engineering Research and Development. Vol. 3, No. 1, p. 18.

Elinwa, A. U - Awari, I. A. (2001): "Groundnut Hush Ash concrete". Nigerian Journal of Engineering Management. Vol.12, No. 1, pp. 8-15.

El-Sayed, M. A. - El-Sanmi, T. M. (2006): "Physical and chemical properties of Rice Straw Ash and its effect on the cement paste produced from different cement types". J. King Saud University. Vol. 19, Eng.Sc (1), pp. 21-30.

Falade, F. A. - Ikponmwosa, E. E. (2006): "Scope of Bamboo Reinforcement in Concrete Beams for Low-Cost Housing". Journal of Construction and Materials Technology, (NBRRI), Accepted for publication in Vol .3, Nos. 1-2
Ikponmwosa, E. - Falade F. (2006): "A Study on the Properties of Fibre Reinforced Laterized Concretes". Journal of Raw Materials Research, Vol. 3, No.1, pp. 46-55.

Okafor, F. O. (1988): "Palm Kernel Shell as a Lightweight Aggregate in Concrete". Cement and Concrete Research, Vol. 18/6.0, pp. 901-910.

Okpala, O. C. (1987): "Rice husk ash as a partial replacement of cement in concrete". Proceedings of Annual Conference. Nigerian Society of Engineers.

Olanipekun, E. A. - Olusola, K. O. - Ata, O. (2006): “A Comparative Study of Concrete Properties Using Coconut Shell and Palm Kernel Shell as Coarse Aggregate". Building and Environment, Vol. 41/3, pp. 297-301.

Oluyemi-Ayibiowu, B. D. - Aderinola, O. S. (2007): "Evaluation of kernel shells as construction materials for low cost houses". Nigerian Journal of Engineering Management. Vol. 8, No. 3, pg 10.

Neville, A. M. (1989): Properties of Concrete, 5th ed, Longman Scientific and Technology, London.

Orchard, D. F. (1976): Properties of Materials. Concrete Technology Vol. 1, Third Edition, Published by Applied Science Publisher Ltd., London.

Sivaraja, M. - Kadasamy, S. - Velman, N. - Sudhakaram, N. P. (2010): Study on Durability of Natural Fibre Concrete Composite using Mechanical Strength and Microstructural Properties, Vol. 5, No. 6, pp. 45-50.

Suvanispan, S. (1988): Mechanical Properties of Palm Fibre Cement Composite Containing Rice Husk Ash. M. Eng. Thesis, Asian Institute of Technology, Bangkok.

Yunusa, A. - Danladi, E. (2013): Properties of Concrete made wit Ordinary Portland Cement Partly Replaced with Rice Husk Ash and Pulverized-Fuel Ash. Journal of Engineering and Applied Science, Vol. 5, No .2, pp. 27-32. 